\title{
A ZAGA DE LA HUELLA DE MIS TRES MAESTROS: MIGUEL ASÍN PALACIOS, IBN 'ARABĪ Y SAN JUAN DE LA GRUZ
}

\section{Luce López-Baralt}

Universidad de Puerto Rico

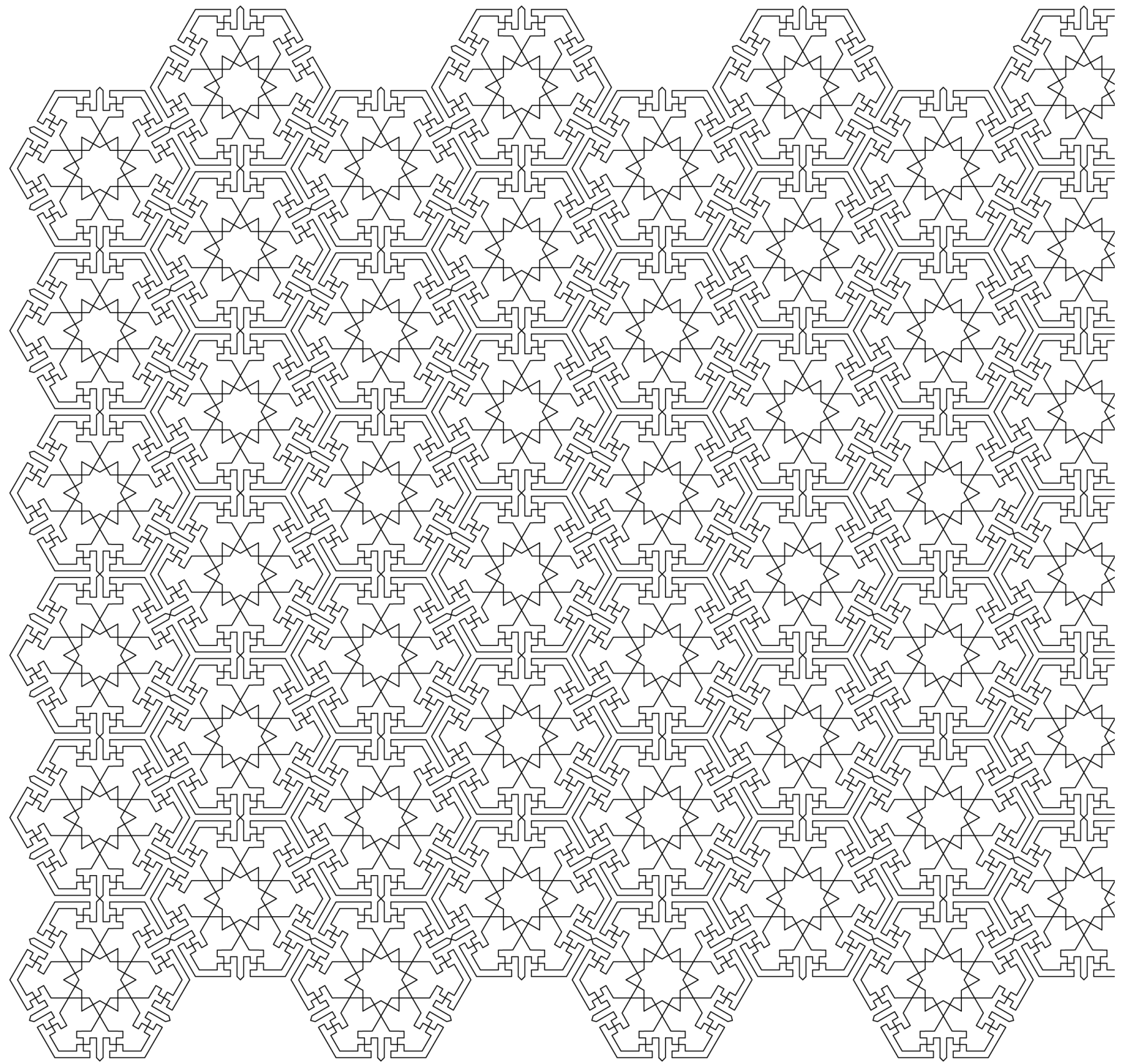


Admito que he llegado a sentir envidia de los discípulos que alcanzaron a estudiar en las aulas con el máximo arabista español, Miguel Asín Palacios. Aunque no lo conocí nunca, nuestras vidas sí estuvieron a punto de cruzarse en este mundo: Asín muere en San Sebastián el 12 de agosto de 1944, tan solo unos días antes de que yo viera la luz en San Juan de Puerto Rico el 21 de agosto. Quién sabe si en el barzah el maestro me animó para que siguiera la pista de los estudios que no alcanzó a completar en vida. Este misterio pertenece a esferas más altas, pero lo cierto es que andando los años habría de dedicar mi vida de estudiosa precisamente a continuar la obra comparatista de Asín.

Quisiera evocar la faceta docente del insigne arabista, pues fue legendaria en los cursos que impartió en la Universidad Central de Madrid a principios de siglo XX. Dámaso Alonso recuerda con nostalgia la clase en una evocación que un día me leyó, conmovido, en su casa de Chamartín de la Rosa:

Asín está sentado sobre su mesa. Los impecables hábitos juegan admirablemente con su figura [...] ¡Qué gozo estar en la clase de Asín! ¡Qué hilos de simpatía salen de cada uno de los [..] discípulos y van a juntarse y a aureolar la figura del maestro! [...] Aquella clase de Asín no se parecía a nada de lo que yo conocía o conoceré en enseñanza oral. Es en mi recuerdo el ejemplo vivo -químicamente puro, inigualable e irrepetible- de lo que puede ser la enseñanza directa de ser humano a ser humano. Algo casi maternal. Así nos nutríamos, con esa admirable regularidad creciente que la naturaleza repite en cada nidada de polluelos. [...] Al cabo de unos meses leíamos sin vocales. Al despedirnos don Miguel nos dijo que dedicáramos al árabe cinco minutos todos los días y no lo olvidaríamos. ¡Ay si lo hubiéramos hecho! ${ }^{1}$

Asín también tuvo sus momentos de impaciencia pedagógica con aquellos alumnos de principios de siglo. El mismo Dámaso Alonso recuerda que “era sólo en muy rara ocasión [que] los nervios -ante un disparate mayor de la marca- se le disparaban: una palabra interjectiva, dura calificación del alumno, se le escapaba...pero enseguida le pedía que le disculpase"2. Supe de estos exabruptos ocasionales de labios de otro de los alumnos más distinguidos de Asín -Jorge Guillén-. Mi antiguo amigo imitaba con gracia los lapsus linguae involuntarios que su profesor, frustrado, dirigía a algún desaplicado: “¡Estúpid...! (Perdone ud., perdone ud.)”. Don Jorge aún se sentía avasallado ante la sabiduría del profesor de sus años mozos: en una carta que me escribió en 1976, exclama con entusiasmo: “iDon Miguel Asín! ¡El mejor profesor que he tenido en toda mi vida!”. Pero debo a Eulalia Galvarriato un dato que tanto Dámaso Alonso como Guillén prefirieron pasar por alto: la notoria apostura y el porte majestuosos de Asín Palacios hicieron suspirar a las alumnas de la Facultad de Letras.

1 Dámaso Alonso, "En un homenaje a la memoria de Miguel Asín”, en: Obras completas, Madrid: Gredos (1975), vol. IV, p. 447.

2 Dámaso Alonso, op. cit., p. 449. 
Pero el maestro también adiestró a sus alumnos a fichar, según él mismo hacía, su material de acopio para preservar las ideas de trabajos futuros ${ }^{3}$. No solo entregaba a sus colegas sino a sus alumnos los temas de trabajo que no tenía tiempo de hacer él mismo. La sobrina-nieta del maestro, Dolores Oliver, lo recuerda:

Para Miguel Asín, el maestro debe sentarse al lado de sus discípulos a investigar, enseñarles cómo deben hacerlo, [...] prepararles bibliografía, corregir sus escritos y, sobre todo, entregarles todas aquellas ideas que él no vaya a utilizar [..].

Él decía a mi padre [Jaime Oliver Asín]: "Cuando hayas dado forma a una idea, publícala aunque la consideres incompleta, ya tendrás tiempo de volver sobre ella para ampliarla" [...] Asimismo le repetía: "no temas equivocarte; lo importante es ser sincero y trabajar siempre con ánimo desapasionado y rigor científico". "Nunca sientas vergüenza de cometer errores, todos los hacemos, ya publicarás otro artículo, rectificando". [...]

Otro de los consejos prácticos que daba Miguel Asín era el de vencer la tentación de dejar un trabajo iniciado [...] El tío siempre aconsejaba a mi padre [Oliver Asín] que, cuando estuviera investigando sobre un determinado tema y creyese haber hecho un nuevo descubrimiento, no dejara nunca lo que tenía entre manos, porque entonces terminaría perdiéndose. Le decía: «Jaime, cuando esto te ocurra, coge una ficha, escribe: "Idea para un trabajo"», apunta esa interrogante que te planteas y olvídate de ella hasta que concluyas el artículo o el libro iniciado".

Éste es el insigne maestro que hubiera deseado tener en vida. En todo caso, la totalidad de mis estudios comparatistas han constituido una larga conversación con Asín, en la que muchas veces he aumentado el acervo de sus hallazgos y otras he actualizado - o matizado- alguna de sus hipótesis. Un sufí asociaría a mi maestro invisible con el legendario al-Hadir - "El Verdeciente" de la azora 18 del Corán- aquel guía espiritual de los que no tienen un maestro visible en este plano terrestre. Por cierto, que Ibn 'Arabī se refiere varias veces a sus encuentros esotéricos con Al-Jadir en su Futūhāt al-makkīya, material que Miguel Asín dio a conocer en su Islam cristianizado (Hiperión, Madrid, 1981). Tan hondo ha sido mi diálogo escriturario con Asín Palacios, que al momento de preparar el prólogo de la edición de su libro póstumo Šádilies y alumbrados que me encomendó la editorial Hiperión de Madrid en 1990, confieso que hubo momentos en los que no sabía exactamente dónde comenzaba

3 Sobre estas fichas de trabajo cf. mi estudio, "Notas de acopio [de Miguel Asín] para futuros trabajos sobre temas de mística comparada (ca. 1919-1934)". en Luce López-Baralt, ed., Repensando la experiencia mística desde las insulas extrañas, Madrid: Trotta, 2013, pp. 479-498).

4 Dolores Oliver, op. cit., p. 29. 
el pensamiento del maestro arabista y dónde terminaba el mío. Las pesquisas a las que habíamos consagrado nuestras vidas era demasiado cercanas, y nuestras vocaciones comparatistas demasiado afines. Quisiera dar fe de la curiosa cercanía afectiva que me une al maestro arabista. Justo después de editar los Šádilies, lamenté no haber podido celebrar con el propio Asín el libro que habíamos compartido. Pero la afinidad de las almas salva fronteras improbables. Había viajado con mi marido y mi madre a Islandia y, con los modestos honorarios que me había pagado Hiperión, en nombre de Asín invité a mi marido y a mi madre a cenar al mejor restaurante -creo que el único-de Reikjavic. Pensaba gozosa: ¡quién le hubiera dicho a Asín en 1944 que habría de invitar a una discípula aun no nacida y a su familia a cenar en la última Tule con el pago generado de la edición del libro que tuvo que dejar póstumo!

Digamos algo sobre la trayectoria intelectual del insigne maestro. Asín consideró que sus Šădilies y alumbrados, el último libro de su vida, constituía la culminación de todos sus estudios previos en materia de espiritualidad arábigo-española: "me atrevo a creer que el panorama, entonces previsto [...] como vaga adivinación, quedará ahora [..] puesto a plena luz" ${ }^{\text {". }}$. Coincido con Asín: este es su libro más valiente, la cima de su pensamiento. En sus primeros trabajos advertimos aun una cautela excesiva por parte del arabista para con los textos del misticismo islámico. Asín se sentía impelido a "prestigiar" el sufismo dotándolo de un influjo cristiano que lo acreditara como posible tema de estudio. Tanto así, que en su Islam cristianizado. Estudio del "sufismo" a través de las obras de Abenarabi de Murcia (Madrid, 1931) se anima a refutar la teoría de Louis Massignon sobre el origen autónomo del sufismo para proponerle un remoto origen cristiano. Los mismos títulos de estos ensayos pioneros dan fe del afán "cristianizador" que tuvo por aquel entonces el estudioso: cabe también recordar en este sentido La espiritualidad de Algazel y su sentido cristiano (1935). Hay que esperar a 1941 para que Asín invierta el título y privilegie el impacto islámico sobre los textos cristianos: ahí están sus Huellas del Islam: Santo Tomás de Aquino, Turmeda, Pascal, san fuan de la Cruz y sus Šădilies y alumbrados póstumo, que culminan esta tendencia. En este libro, lamentablemente inconcluso, Asín privilegia la impronta de los textos musulmanes sobre los peninsulares, y demuestra que buena parte de la imaginería que habíamos pensado exclusiva de san Juan y santa Teresa de Jesús fue preludiada por los sufies hispanoafricanos: los estados alternos de la anchura y la estrechura del alma; la noche oscura como morada de los aprovechados; la metáfora del relámpago para el rapto súbito; el espejo del alma y, en especial, el símbolo de los siete castillos concéntricos del camino hacia la unión mística transformante. El símil que santa Teresa haría famoso en el siglo XVI y que no tenía paralelo en la mística occidental encuentra aquí, por primera vez, su contrapartida en un texto anónimo, los Nawādir, que Asín había logrado documentar. El misticismo musulmán le llevaba pues una gran ventaja al peninsular, y sirvió de vehículo para cantar los más hermosos extremos de amor místico que cuatro siglos más tarde asociaríamos con nuestras figuras espirituales más prestigiosas.

5 Cf. Miguel Asín Palacios, Šādilies y alumbrados, Madrid: Hiperión, 1990, p. X, nota 1. 
Asín parecería haber profesado una veneración (¿inconfesada?) por los antiguos maestros del Islam que solo al final de su vida se atrevió a proponer como posibles fuentes literarias de los místicos carmelitas. Que una cosa es ver la impronta islámica en la Divina comedia de Dante (hipótesis que Asín propone ya desde 1929) y muy otra verla reflejada en su propia literatura patria. En sus Šădilies respetuosa pero dolidamente increpa al maestro Marcel Bataillon el que echara de lado a los "rudos e incultos moriscos" como posibles antecedentes de la mística española del siglo XVI. Bataillon, como se sabe, privilegió en su Erasmo y España los posibles antecedentes judeoconversos para el misticismo de vanguardia del XVI, pero Asín le replica documentando en su libro póstumo lo sofisticada que fue la literatura mística de Al-Andalus y de África durante los siglos medios. (Hace años compartí con Bataillon uno de mis propios ensayos comparatistas, en los que seguía los pasos de Asín, y tuvo la entereza de darnos la razón. Ojalá hubieran podido dialogar más los dos insignes maestros.)

Hoy nos resulta curioso que Asín Palacios, para poder manejar con comodidad los textos místicos musulmanes, se preocupara de asegurar la plausibilidad de que éstos celebraran estados extáticos auténticos. El arabista, sirviéndose del teólogo católico P. Garrigou-Lagrange, asegura que las gracias místicas son posibles fuera del cuerpo de la Iglesia (Pról., p. 21): sus amados sufíes estaban pues dando cuenta de dones místicos genuinos. No olvidemos que Asín fue sacerdote y que escribía en unos años en los que podría parecer arriesgada tanta admiración por una literatura extática al margen de la ortodoxia cristiana.

Las actitudes que Miguel Asín guarda respecto a su propio campo de investigación están aún por estudiar. Su postura ideológica frente al corpus literario musulmán al que dedicó toda su vida ha sido algo fluctuante, y va desde un intento de declarar que los textos sufies visionarios eran teológicamente aceptables, pasando por su supuesta "cristianización" esencial, hasta dar paso a su privilegiación entusiasta como posibles fuentes del misticismo hispánico. Es de lamentar en este sentido que Edward Said no se ocupara de los arabistas españoles, de los que Asín es el máximo representante, en su libro Orientalism (1979). Por cierto que le reclamé a Said su hiato, y me respondió con candor que él apenas conocía el orientalismo español. Falta mucho que reflexionar sobre el orientalismo hispánico, que nace, por el contrario al del resto de Europa, en un suelo que durante siglos fue parcialmente oriental. Esta situación aún causa interrogantes ontológicas curiosas: al prologar el libro de las Poetisas de al-Andalus de María Jesús Viguera, María Ángeles Durán se pregunta “ise trata de un ellas, o de un nosotras?"

La misma pugna interior de Asín ante la extrema privilegiación del sufismo se puede adivinar en su actitud, otra vez más, algo equívoca, frente a la espiritualidad de la India, cuya lengua sagrada, el sánscrito, estudió de joven. Tenemos noticia de ello porque la arabista Dolores Oliver, sobrina-nieta de Asín, tuvo la generosidad de legarme un nutrido conjunto de cartas, ensayos, libros y fotografías de su ilustre tío entre los que se encontraba un curioso Cuadernillo de sánscrito. Al regresar a Puerto Rico y hojear aquellos inéditos sagrados, un intenso olor a cigarrillo permeó mi biblioteca. ¡Había olfateado 
el aroma de don Miguel a tantos años de su muerte! Me decía su sobrina que su tío fumaba en cadena y tenía los dedos manchados de nicotina. Fue como haber tenido por unos instantes al maestro de visita en mi propio estudio.

Llevé a cabo la edición de muchas de las notas de acopio de temas místicos comparados de Asín en Trotta $(2012)^{6}$, y fue como colocarme a hurtadillas tras su hombro para ver cómo preparaba los libros que luego lo harían tan famoso. Ya junto a la sanscritista Gloria Maité Hernández me encargué de la edición y estudio de tres libros inéditos de Asín que trataban de temas orientales: el Cuaderno de lengua sánskrita, la Historia de la filosofia y la Historia Philosophiae. El libro vio la luz en Ediciones Mandala de Madrid en 20157: Miguel Asín Palacios, estudiante de la lengua sánscrita y profesor de la filosofía religiosa de la India. Estos antiguos volúmenes de Asín resultan invaluables para trazar la prehistoria de su pensamiento teológico, místico y comparatista.

Una lectura atenta de estos libros me ha permitido percibir que la misma tensión interna que el estudio del sufismo generó en Asín también la vemos presente en sus estudios de la lengua sánscrita y la filosofía religiosa de la India. El arabista, ya se sabe, era un hijo del siglo XIX y un sacerdote católico muy cauto desde el punto de vista teológico. Pero a la vez era un enamorado de Oriente, y una vez se oye el llamado de esa voz ultra auroram et Gangem -"más allá de la aurora y del Ganges", por decirlo con palabras de Juvenal- ya es difícil sustraerse de su fascinación.

El estudio del sánscrito, como asegura Juan Álvarez Pedrosa, estaba plagado de tensiones en los primeros años del siglo XX. Pero Asín era un espíritu independiente, y aprendió la lengua con el mismo esmero e independencia con el que se lanzó, muy joven aún, a sus primeros estudios. Él mismo confiesa la rebeldía con la que redirigió de manera autodidacta su programa de estudio, a todas luces ineficiente en la Zaragoza de fines del XIX:

No sabía latín, apenas sabía francés, no podía leer un pergamino, ni había visitado un archivo; no podía conocer ni una moneda, ni una inscripción, ni un monumento; no sabía hacer más que lo que vi hacer a mis maestros y compañeros; leer y repetir, [..] retazos de libros; a esto sólo me habían enseñado [...]. Hice examen de conciencia y me encontré desnudo; con ardor de neófito me condené a silencio temporal, cesé de perorar en Ateneos y Academias, repasé latín y francés, comencé el estudio del alemán y del inglés, la paleografí; [y] al fin pude trabajar personalmente en la investigación...

6 Cf. mi citada edición "Notas de acopio para futuros trabajos sobre temas de mística comparada (ca. 19191943), Miguel Asín Palacios".

7 Miguel Asín Palacios, estudiante de la lengua sánscrita y profesor de la filosofia religiosa de la India, Madrid: Mandala, 2015). 
Por eso no me asombra demasiado constatar que, pese a que Asín cursó la clase de sánscrito en la Universidad Central de Madrid con el Profesor Juan Gelabert en el curso de 1894-1895, el cuadernillo de su propia autoría, escrito en grafía devanagari, no consta de simples apuntes de clase, sino que constituye un compendio de distintos materiales para el estudio de la lengua. El conocimiento del sánscrito, imprescindible por aquel entonces para una formación filológica erudita, constituía el puente hacia los estudios de religión comparada. ${ }^{8}$ Ya sabemos que este estudio se convertiría en la más profunda pasión de Asín Palacios ${ }^{9}$.

Los otros dos cuadernos inéditos -la Historia de la filosofia y el más abreviado Historia philosophiae, redactado en latín- nos asoman, de otra parte, a las reflexiones de Asín en torno a la cultura religiosa de la India, que enseñó en el Seminario Conciliar de Zaragoza hacia 1899. Ya dije que el estudio de la filosofia religiosa de Oriente era muy polémico en la época, hasta el punto de que algunos sanscritistas fueron excomulgados -literalmente- como "ocultistas" heterodoxos. El entonces joven aragonés hace escuela con el mejor indólogo de España, Francisco García Ayuso, de tradición católica, que usaba la filología y la religión comparada para argumentar el carácter cristiano de las tradiciones orientales. Asín oscila, como adelantamos, entre condenar el pensamiento budista, egipcio y persa en algunos pasajes y en enaltecer "su perfección intrínseca" en otros. Tanto así que a veces sospecha que ha ido demasiado lejos en su exaltación teológica, y se repliega con cautela, matizando sus aseveraciones. No le sería fácil asomar a sus estudiantes a una cultura religiosa sofisticada que podría exponerlos al peligro de la heterodoxia. Pero ya aquí está germinando, no cabe duda, el arabista que en el futuro habría de establecer diálogos respetuosos y aun admirados con el sufismo islámico.

Asín intervino, bien que de manera discreta, en las polémicas que el estudio de las lenguas asiáticas y semíticas suscitaba por aquellos años en España, y sus inéditos resultan invaluables porque nos permiten intuir, como adelanté, que debajo de su prurito ortodoxo, y pese a la censura religiosa de la época, latía una evidente admiración por la espiritualidad oriental. El conflicto que le produjo a Asín su condición de maestro y de estudiante de estos temas indológicos volvería a ser evidente cuando años más tarde se convirtiera en un arabista célebre que habría de medir su campo de estudio a la luz de la ortodoxia cristiana. De haber vivido más años, sospecho que Asín hubiera seguido privilegiando su propia libertad intelectual y religiosa: justamente la que dejó traslucir en su libro póstumo Ša dilíes y alumbrados.

Esta es precisamente la línea de pensamiento de mi maestro invisible que he seguido en mi propia vida de estudiosa. Mis libros, que siempre lo homenajean, optan por el "cristianismo islamizado", más que por el "islam cristianizado". Pese a mi diálogo constante con Miguel Asín, debo decir que

$8 \mathrm{El}$ origen de los estudios de religión comparada se encuentra precisamente en los estudios de lingüística comparada, sobre todo en las conferencias dictadas por el lingüista alemán Max Müller durante la década de 1879-80 (Cf. Tomoko Masuzawa, The Invention of the World Religions, Chicago: The University of Chicago Press, 2005, p. 209).

9 Masuzawa, op. cit., p. 209. 
comencé mis estudios comparatistas al margen del magisterio de sus libros. Fue una curiosa confluencia, cierto que con sabor a misterioso reencuentro. Comencé a estudiar el árabe de adolescente -sin haberlo escuchado nunca-, por una extraña afinidad por la cultura islámica que nunca me he podido explicar. Un buen día me volví a enamorar. Fue ya en mis años universitarios, cuando leí a san Juan de la Cruz, y la sacudida que sentí frente a sus liras embriagadas, que tanto intimidaron a Menéndez Pelayo y Dámaso Alonso, fue tal que me llevó a acometer la extraña aventura de escribir una tesis doctoral en Harvard simplemente para explorar el asombro que me producían estos versos místicos. Una tarde afortunada expliqué a una amiga de Bagdad, Wasma'a Chorbachi, que no comprendía el delirio verbal de San Juan, ni su alucinante simbología mística, ni las glosas "aclaratorias" que añaden aún más enigma a sus versos. Wasma’a me dijo que lo que me parecía tan raro le era en cambio muy familiar. Y me instó a leer los versos regocijados de Ibn al-'Arabī y de Ibn al-Fāriḍ: vi enseguida que el lenguaje aleatorio de mi poeta no sólo imitaba los deliquios del Cantar de los cantares, sino que era cónsono con las casidas místicas de los sufies. La estructura molecular de sus poemas era típicamente árabe, así como sus enigmáticas glosas aleatorias, mientras que muchos de sus símbolos místicos correspondían al trobar clus codificado de la mística islámica. curiosamente, el misterio poético de san Juan me había devuelto a mi amor inicial por la cultura árabe. La islamóloga Annemarie Schimmel me explicó a su vez que nunca le había parecido extraño San Juan porque lo leía "como si fuera un sufi". Algo tenía que explicar que una estudiante de Bagdad y una islamóloga alemana sintieran "familiar" al poeta que tanto asombraba a los estudiosos occidentales.

Jorge Guillén, que vivía en Cambridge y estaba al tanto de mis investigaciones, fue quien me habló por vez primera de Miguel Asín, su maestro en la Universidad Central de Madrid, y me animó a leerlo para seguir investigando el extraño arte -“misterioso como un aerolito", como diría Dámaso Alonso- de san Juan de la Cruz. Mis profesores, por su parte, me enviaron al Líbano a estudiar el árabe y el misticismo islámico de manera formal.

Allí fue que conocí el estudio de Asín en torno a los siete castillos concéntricos de santa Teresa y su contrapartida islámica. Lejos estaba yo de saber que años después habría de editar el libro póstumo Šádilíes y alumbrados, donde se encuentra el célebre ensayo, y que habría de añadir casos adicionales al texto anónimo de los Nawādir, el primero que apunta el arabista como antecedente teresiano. Asín, sin embargo, no logró probar más allá de toda duda que este tratado era previo a las Moradas de santa Teresa, porque era del siglo XVI, por lo que pudo haber sino posterior o contemporáneo de la santa. Tuve, sin embargo, la fortuna de dar la razón al maestro al descubrir varios autores adicionales que dibujan el esquema de los siete castillos con siglos de antelación a la Reformadora: Abū l-Ḥasan alNūrī, autor de las Maqāmāt al-qulūb o Moradas de los corazones y al-Hakīm al-Tirmidīi, autor del Gawr al-umūr o Libro acerca de la profundidad de las cosas, fraguaron el símil en el siglo IX. Muhamad b. Mūsà al-Dāmirī, autor del Diccionario de historia natural o Kitäb hayāt al-hayawān, repite el símil en el siglo XIV. Tenemos pues documentado el esquema de los siete castillos concéntricos en el siglo IX (dos casos), en el siglo XIV y en el siglo XVI: estamos ante una imagen recurrente en el Islam. Es fuerza dar 
razón a la hipótesis de Asín, que propuso justo antes de morir un posible origen islámico para los castillos o moradas teresianas.

Retomé entonces el hilo de otro riquísimo filón de los estudios del maestro: la simbología mística secreta que san Juan de la Cruz - y su hermana de hábito Teresa- comparten con los sufíes. San Juan parece manejar el trobar clus de los sufies del medioevo, cuya clave poseían, según Louis Massignon, exclusivamente los iniciados ${ }^{10}$. Miguel Asín ${ }^{11}$, como adelanté, había documentado algunos de estos símbolos, como la noche oscura del alma, que san Juan comparte con Ibn 'Abbād de Ronda. Le dí la razón una vez más cuando identifiqué una treintena de símiles adicionales de raigambre sufí que los místicos españoles parecerían haber aclimatado a su cultura cristiana: las lámparas de fuego, las azucenas del dejamiento, el pájaro solitario, que tiene todos los colores, pero que no posee determinado color; la "dulce Filomena" que se comporta como el jubiloso bulbul sufi que canta al éxtasis, a desprecio de su melancólico nombre griego, entre otros. Reuní mis hallazgos en un libro que no ha circulado en Occidente porque lo publiqué en inglés en Lahore, Pakistán, en 2000: The Sufi trobar clus and Spanish Mysticism: a Shared Symbology ${ }^{12}$.

En el fondo no hay mejor manera de homenajear un maestro que seguir fervorosamente sus huellas. Por eso, en honor de Miguel Asín, paso ahora a explorar un símil que no obra en mi libro pakistaní pero que viene a aumentar el legado comparatista arábigo-español del maestro, pese a que escapó a su conocimiento. San Juan dialoga de cerca con Ibn 'Arabī - nada complacería más a Asín- cuando intenta darnos noticia de la cima del éxtasis. Las hipótesis comparatistas de mi maestro invisible aún están vivas a los 70 años de su muerte. Entremos en materia.

Ha anochecido inesperadamente. En medio de las tinieblas un manantial encendido pulsa rítmicamente: diamante vivo en la noche oscura. La cristalina fuente de semblantes plateados en oscilación regulada mana en la noche iniciática del "Cántico espiritual" y marca el momento en el que la Esposa enamorada detiene la búsqueda febril de su Amado y se coloca en la antesala misma del re-encuentro.

Para explicitar el espacio simbólico -el sagrado "adónde"- en el que la Esposa reencuentra al Amado, fugitivo como ciervo en la lira que inaugura el poema, el poeta urde una simbología mística completamente novedosa. Nos dice, en primer lugar, que concibe el alma como un "corazón" simbólico -"El corazón significa aquí el alma" (CB 12,8) - apoyándose en un versículo del Cantar de los Cantares, "Ponme como señal sobre tu corazón".

10 'Omar Ibn Al-Faridh, L’Éloge du vin (Al Khamriya, Poème mystique), París: Les Éditions Véga, 1932, pp. 62-63. La traducción española es de Carlos Varona Narvión, Madrid: Hiperión, 1989.

11 Cf. sobre todo "Un precursor hispano-musulmán de San Juan de la Cruz", en Al-Andalus I (1933), pp. 7-79, y el citado Šădilies y alumbrados, introd. Luce López-Baralt, Madrid: Hiperión, 1990.

12 Traducción de Andrew Hurley, Lahore: Iqbal Academy, 2000. 
Pero lo que realmente sugieren los versos sobrepasan por mucho el modesto apoyo bíblico. Sigamos leyendo:

¡Oh cristalina fuente!

Si en esos tus semblantes plateados

formases de repente

los ojos deseados

que tengo en mis entrañas dibujados!

La protagonista del "Cántico", que en su ansioso deambular en busca del Amado recorría montes, riberas y espesuras, detiene su paso para mirarse en el espejo plateado. Y se enfrenta con una sorpresa descomunal: ha perdido su identidad. No tiene rostro ni bulto corpóreo, ya que no se refleja en las aguas encendidas. Lo que la fuente le devuelve tampoco es un rostro ajeno, como sucede en el Platir y el Abencerraje, sino algo mucho más extraño: unos ojos ajenos. Por más, los vertiginosos ojos del Amado reflejados en la alfaguara son simultáneamente de Él y de ella, ya que donde están grabados es en las propias entrañas - el "corazón" interior- de la que se mira en el manantial. Ella los mira y ellos la miran desde las aguas y no es posible establecer diferencias entre ambas miradas que se auto-contemplan. Inesperadamente, el ansioso " ¿adónde?" que inaugura el poema se nos comienza a contestar. “¿Adónde te escondiste, Amado?". La respuesta es sobrecogedora: "En mí misma”. Por decirlo con palabras de Alfred Lord Tennyson: "the Kingdom is within". O con palabras de San Agustín: in interiore hominis habitat veritas.

Curioso "corazón" cristalino dotado de autocontemplación trascendente. La Amada, fuente sellada como la Sulamita de los Cantares (IV,12), se ha transformado en el Amado gracias a la magia proteica de una fuente que refleja, cual espejo sobrenatural, una mirada que va en ambas direcciones a la vez. Parecería que estamos ante el simbólico ojo del alma que celebraron como órgano de percepción mística Platón y San Agustín. Ibn 'Arabī de Murcia también lo supo: "Cuando aparece mi Amado ¿con qué ojo he de mirarle? Con el suyo, no con el mío, porque nadie le ve sino Él mismo”. El simbólico espejo del corazón le devuelve a la protagonista poética una identidad trascendida, ya que intentaba contemplar en él a Dios y termina contemplándose a sí misma en Dios. Michael Sells resume esta unificación mística suprema: "La visión (la mirada de un sujeto hacia un objeto exterior) ha devenido auto-visión [cuando] la Divinidad se revela a Sí misma en el corazón del místico"13. Queda pues sola la mirada transformante flotando encendida sobre las aguas.

Los ojos trascendidos queman a la Amada, que tiene que rogar: "apártalos, Amado, / que voy de vuelo". Los ojos divinales se "salen" de la fuente, cobrando vida propia. La línea divisoria que separa al alma de Dios es sutilísima y acaba de romperse. La amada anuncia que "va de vuelo". Pero ¿cómo va a volar hacia esos ojos, si los dejó hundidos en la fuente? Estamos ante una súbita simultaneidad 13 Michael Sells, "Ibn ‘Arabī ‘s Polished Mirror. Pespective Shift and meaning Event”, Studia Islamica 66 (1988), pp. 121 y 131. 
de direcciones: la amada vuela, pero no hace otra cosa que hundirse en la fuente de sí misma. Allí encontrará, como Narciso, la muerte, pero la muerte será para ella no la extinción sino la transmutación del ser. Narcisismo pues sublime y desculpabilizado. El espacio y las perspectivas se anulan como en un espejo invertidor: la amada no traza realmente camino. Dentro de este "corazón" simbólico, ir al Amado es ya ir hacia ella misma.

El mandato del Esposo, que ahora habla por vez primera en el poema, parecería otro sin sentido: "vuélvete, paloma, / que el ciervo vulnerado/ por el otero asoma/ al aire de tu vuelo,/ y fresco toma". "Volverse" puede significar tanto "ir" como "venir", y el poeta, curiosamente, nos dice que la orden del Amado debe entenderse de las dos maneras a la vez (CB 14-15,9). La amada, que no sabía si iba o si venía hacia el Amado, recibe ahora de éste una orden para que se retire y a la vez para que acuda a Él: es que el desplazamiento no puede ocurrir porque ya no hay distancia que recorrer entre ambos. Los dos caminos han quedado invalidados: los amados comparten el mismo espacio sagrado. El mandato "vuélvete", de otra parte, puede entenderse también como "transfórmate" o "conviértete en Mî”. En el receptáculo simbólico de este "corazón” acuoso, ya lo sabemos, se funden las identidades en Uno.

La protagonista transmuta ahora su identidad por la de una paloma, símbolo del alma fiel en vuelo místico. El Amado, por su parte, se funde en un "ciervo vulnerado", símil semítico para la belleza masculina y el ardor pasional. El vuelo de la paloma y el desplazamiento del ciervo, ahora prodigiosa danza de Siva, es, una vez más, de ambos, que cortan el aire en dirección mutua en un camino inexistente. La herida que la amada había recibido del ciervo en la primera lira del poema se ha canjeado y ahora es de él en el espejo invertidor de este "corazón” místico donde todo es reversible.

La enamorada celebra ahora el hallazgo del Amor Indecible y la fusión gozosa que le es intrínseca:

Mi Amado, las montañas,

los valles solitarios nemorosos,

las ínsulas extrañas,

los ríos sonorosos,

el silbo de los aires amorosos;

la noche sosegada

en par de los levantes de la aurora,

la música callada,

la soledad sonora,

la cena que recrea y enamora.

Nuestro lecho florido

de cuevas de leones enlazado

en púrpura tendido 
de paz edificado

de mil escudos de oro coronado.

Este conjunto de liras, con su curiosa ausencia del verbo "ser", al uso semítico, implica otra lección mística: este verbo ya no se necesita porque la identidad de Dios ya no se encuentra separada de la del alma: los enamorados son lo mismo que aman y ya no podemos distinguir entre ambas esencias unidas. El anhelante torrente de imágenes inconexas, de otra parte, produce el efecto de un conjuro incantatorio: Dios no entra al alma por vía de la razón, y por ello mismo san Juan pone sordina a nuestras facultades racionales en el espacio sagrado del corazón místico.

La Esposa, que buscó a su Amado en los paisajes exteriores - montañas, noche, música, lecho nupcial- descubre ahora que Él incorpora en su Esencia esos tiempos y espacios, ahora trascendidos, donde su buscadora lo intentaba encontrar en vano. El angustioso “¿adónde?" inicial se nos vuelve a contestar con esta miríada de imágenes en gloriosa sucesión caleidoscópica. El Amado no tiene rostro - no lo reflejó en la fuente- y se concibe bajo el símil de una cascada vertiginosa de espacios y de tiempos: Dios redime en Sí mismo a la creación, unificada en Él, en el espacio infinito del corazón espejeante de la amada. El órgano cordial de la percepción mística deviene pues el eje sobrenatural donde confluyen cielos y tierra.

Los versos conllevan aún más claves místicas. Ya sabemos que la Esposa descubre que Dios incluye en Su Ser los espacios donde ella lo buscaba, y que esta identidad infinita de su Amado se completa en la apreciación de ella, en ella: "Estas montañas es mi Amado para mí". Insiste el poeta-comentarista: "todas estas cosas [montañas, ríos, valles] es su Amado en sí y lo es para ella" (CB 14-15, 5). En el intercambio altísimo de amor, Dios la ha transformado en Sí, pero también ella es quien sirve de metafórico espejo a la identidad cambiante del Amado: Él es esta miríada de maravillosos espacios y músicas y noches porque lo es en la apreciación de ella, que ha devenido infinita en unión participante. Ambos son el espejo del otro, y se devuelven su ipseidad en una sucesión interminable de espejos que se auto-reflejan sin fin como si se encontraran el uno frente al otro. Nadie había celebrado el éxtasis como proceso dinámico vertiginoso en la mística occidental.

Salta a la vista que el espejo de este corazón proteico es capaz de reflejar cualquier epifanía divinal, sin atenerse a ninguna. Dios es infinito e inasible, como apunta San Juan: "ni los ángeles le pueden acabar de ver ni le acabarán..."; "Sólo para sí no es extraño [Dios], ni tampoco para sí es nuevo" (CB 14-15,8). No hay pues por qué atarse a ninguna de estas manifestaciones, porque sólo Dios puede terminar de conocer de veras sus epifanías sin término. Por esto el poeta derrochó su vehemente surtidor de visiones con tanta alegría indeterminada: Dios es los espacios, los tiempos, la música, y no es sólo una de esas cosas, sino todas y aún infinitas más, porque de la febril celebración enumerativa se desprende que la recepción de estos atributos no acaba nunca. 
La fisiología sutil de este órgano cordial de percepción mística entendido como espejo fluctuante capaz de reflejar los atributos incesantes de Dios en vertiginoso cambio perpetuo no tiene antecedentes en la mística cristiana, y de esa dramática ausencia me he ocupado en estudio aparte. Para el Reformador el corazón no es la simple sede de las emociones, como en los Evangelios, ni se relaciona con el corazón sufriente de Jesús, cuya devoción harían popular las beguinas y luego san Francisco de Sales y santa Juana de Chantal, sino que constituye un eje voluble en cambio perpetuo que refleja las epifanías infinitas de Dios, armonizando así Su Unidad Suprema con el mundo creado.

Los místicos del Islam serán quienes nos ayuden a contextualizar la misteriosa imaginería simbólica de san Juan. Tomarlos en cuenta aquí constituye un homenaje especial que quiero rendir hoy a Miguel Asín, porque sé que si hubiera tenido más vida hubiera sido él quien explorara las semejanzas que san Juan guarda con los sufies en lo relativo a la concepción del corazón profundo como la sede dinámica del éxtasis.

El símil islámico del corazón como locus de la unión mística se hermana con la estilización espiritual de la jóora platónica y de las enseñanzas egipcias, herméticas y alquímicas; y aún con el Taoísmo chino, el Tantrismo de la India y el Budismo tibetano. Pese a las diferencias que guardan entre sí estas escuelas de espiritualidad, todas conciben el órgano místico del corazón como una función dinámica que integra las energías celestes y que a la vez sirve de punto de convergencia entre el cosmos y la subjetividad espiritual del gnóstico.

Los sufies, en sintonía con los planteamientos esenciales de estas tradiciones, articularon sin embargo su órgano cordial de percepción extática con unos matices muy específicos que evocan las teorías de san Juan de la Cruz. El órgano sutil, entendido como receptáculo cristalino y proteico capaz de reflejar todas las epifanías de Dios - la inacabable manifestación de la Divinidad en la morada de la Unión- constituye un símbolo muy conocido en el Islam: el del corazón interior o qalb.

El vocablo árabe qalb, derivado de la raíz $q-l-b$, además de su sentido primario de "corazón", emparenta los significados simultáneos de "centro", "alma", "receptáculo", "cambio perpetuo", "volverse", "convertirse", "transmutarse", "invertirse", "ser reversible". Otros sentidos adicionales son "pozo" (qalib), y "palmito" o "médula de la palmera" (qilb o qulb) 14. Los teóricos islámicos aprovecharon la extrema ductilidad de la voz $q-l-b$ para expresar las distintas modalidades del proceso de la unión mística.

El qalb es, en primer lugar, el "receptáculo" simbólico de la Divinidad. Este "molde" pasivo es por necesidad infinito: de ahí el consolador hadiz o tradición profética en la que Alá asegura que: Ni la tierra ni el cielo pueden contenerme, pero Me contiene el corazón de mi siervo creyente. El vocablo qalb, en la variante 1970; Julio Cortés: Diccionario de árabe culto moderno, Madrid: Gredos, 1995; y J. M. Cowan: Arabic-English Dictionary, Ithaca: Spoken Languages Services Inc., 1976. 
de qălib ("molde" o "receptáculo") pasó al castellano como "gálibo". Aun se usa como término naval de "galibar" para trazar el contorno de las piezas de los barcos. "El gálibo" también es el arco en forma de "U" invertida con el que se mide las dimensiones de los túneles. El término se asocia también con la voz "calibre", es decir, el diámetro interior de objetos huecos como armas de fuego ${ }^{15}$. De ahí también el "cálivo", antiguo instrumento de artillería que medía el peso de las balas ${ }^{16}$. Baste recordar que precisamente en este "molde" o "gálibo" divinal que todavía los hispanohablantes pensamos en árabe es que los sufies contenían la Divinidad en el espacio/molde infinitamente ensanchado de sus "corazones". Si todavía conservamos la voz "gálibo", no es mucho que san Juan conserve en el siglo XVI la concepción mística de este qalb de antigua raigambre árabe.

El "receptáculo" del qalb es espejeante y acuoso. Sólo cuando el espejo del corazón interior se ha pulido es que puede reflejar a Dios. San Juan y Santa Teresa, doctos en estos espejos límpidos del alma, hacen suyo un antiguo leit-motiv que los sufies del medioevo habían elaborado durante siglos. El corazón, ya desasido de lo creado es, metafóricamente, un espejo libre de mácula capaz de reflejar la Divinidad. Pero Dios es infinito, y como las potencias del alma se llenan sólo con infinito, el órgano cordial deviene, a su vez, infinito cuando sirve de azogue a Dios.

La característica más distintiva de este molde espejeante sufí es, de otra parte, su capacidad de movimiento perpetuo. Estamos ante la coincidencia más perturbadora entre san Juan y los musulmanes. El qalb islámico es un espejo dotado de movimiento continuo, que refleja en sí la manifestación constante de los atributos infinitos de Dios. La imagen simbólica surge también de la raíz $q-l-b$, que también quiere decir "cambio perpetuo". La rápida sucesión de las epifanías de Dios en este azogue caleidoscópico del qalb es, claro está, sólo aparente, ya que en Dios, a salvo del tiempo y del espacio, es manifestación simultánea. El lenguaje sucesivo, claro está, no puede dar cuenta de la simultaneidad inherente a la experiencia mística, tan solo sugerirla.

Tengamos presente, de otra parte, que otras tradiciones, desde el judaísmo y el cristianismo hasta el taoísmo chino, consideran negativa la ambivalencia inherente del corazón, capaz de albergar emociones tanto positivas como dañinas. La ductilidad del qalb islámico es, en cambio, gozosa, y gracias precisamente a ella es que el órgano místico sufí deviene capaz de reflejar a Dios. Sólo si el qalb oscila a perpetuidad es que puede espejear la manifestación continua de los atributos infinitos de Dios sobre él. El espejo "cordial” de los sufíes es pues móvil -exactamente como el corazón especular del "Cántico espiritual" de san Juan. Curiosamente, también nuestra lengua registra este movimiento acompasado del qalb con la españolísima palabra "garbo", que apunta al movimiento gracioso -por oscilante- de una persona.

15 14. De la voz gālib también provienen términos arquitectónicos y aún voces asociadas con el concepto de "elegancia", como la tan españolísima palabra "garbo". Agradezco los datos navales al ingeniero naval Manuel Martín López.

16 Julián Ferrofino, Descrizión y tratado muy breve y lo más probechoso de artillería, mss. 1599, fol. 128 y ss., DICTER, M.J. Mancho Duque, e-mail a L. López-Baralt de sept. 13, 2010. 
Semejante noción pasó al catalán como "escalivada", para referirse a una cocción donde se saltean constantemente los vegetales al fuego ${ }^{17}$.

El qalb, sede del cambio incesante, no tiene solidez física, sino "movimiento, oscilación regulada, pulsación permanente" ${ }^{18}$. La "inagotable capacidad [del corazón] para acoger formas e imágenes"19 le permite fluctuar entre una visión teofánica u otra sin atarse a ninguna: Dios las posee todas en Su absoluta Unidad. Sólo con un órgano de percepción en cambio perpetuo podrá el místico manifestar de alguna manera el proceso de su conversión en Dios: por eso los sufíes celebran a su Creador como muqallib al-qulūb ("El que hace fluctuar a los corazones").

Muchos contemplativos islámicos celebran este corazón/qalb que por su condición cambiante sirve de azogue a los atributos de Dios. Al-Buhārī se hace eco de un hadiz que explica la volubilidad del qalb: "el corazón (qalb) del hijo de Adán se encuentra entre dos dedos de Dios. Cuando Él quiere hacerlo fluctuar (taqlīb) lo hace fluctuar". De ahí la plegaria en la que el Profeta Mahoma apostrofa a Dios como "iOh Aquel que hace fluctuar los corazones! (yā muqallib al-qulüb)".

Los tratados sufíes en torno a este órgano de percepción sutil insisten en que “... cambia según va recibiendo las epifanías divinas" ${ }^{\text {. }}$. Abū l-Hasan al-Nūrī fue en el siglo IX uno de los pioneros en la elaboración de este símbolo proteico en sus Maqāmāt al-qulūb. La colección de imágenes aleatorias que se despliegan vertiginosamente frente al lector en estructura de arabesco constituyen una mandala verbal del qalb, un auténtico "evento visionario del alma", por decirlo con palabras de Henry Corbin $^{21}$. Al-Muhāsibī también asegura haber poseído este estado ya libre de toda atadura a las moradas ${ }^{22}$. Hallāğ enseña a su vez que el místico no debía atarse a ningún estado, sino mantener su corazón maleable y receptivo de cualquier forma ${ }^{23}$. Rūzbihān Baqlī (606/1209) insiste en este qalb fluctuante que manifiesta a Dios: “Este corazón se llama ‘corazón' (qalb) porque fluctúa cuando atestigua los atributos"24.

17 Curiosamente, "garbo" es un arabismo que viene a través del italiano, y calibre, a través del francés Cf., entre otras autoridades, María Moliner, Diccionario del uso del español, Madrid: Gredos, 1994. Agradezco, de otra parte, la noticia del catalanismo "escalibada" a Luis Girón.

18 Louis Massignon, La passion de Husayn Ibn Mansûr Hallâj (4 vols.), París: Gallimard, 1975, vol. III, p. 19.

19 Suad Hakim y Pablo Beneito, traductores y editores. Las contemplaciones de los misterios de Ibn 'Arabī. Murcia: Editora Regional de Murcia, 1994, p. xi.

20 Suad Hakim, "Knowledge of God in Ibn 'Arabī”, en Muhyiddin Ibn Arabi. A Commemorative Volume. Stephen Hirtenstein y Michael Tiernan, eds., Londres: Element Books Ltd., 1993, p. 272.

21 Henry Corbin, L'imagination créatrice dans le soufisme d'Ibn 'Arabī, París: Flammarion, 1977, p. 240.

22 Cf. Herbert Mason, "Hallâj and the Bagdad School of Sufism", en: L. Lewisohn, ed., Classical Persian Soufism: from its Origins to Rumi. Londres-New York: Khaniqahi Nimatullahi, 1993, pp. 65-82.

23 Massignon, op. cit., vol. III, p. 32.

24 Sachiko Murata, The Tao of Islam. A Sourcebook on Gender Relationships in Islamic Thought, Nueva York: State University of New York Press, 1992, p. 298. 
Nağm al-Dīn al-Kubrā (s. XIII) explora la condición cambiante de este órgano místico de percepción sutil, que no tiene determinado color - como el pájaro solitario de San Juan de la Cruz y de los persas $^{25}$ - justamente porque asume cualquier color o forma que se refleje en él. Gracias a esta ductilidad es que puede refractar la manifestación simultánea de los atributos infinitos de la Divinidad:

Has de saber que la sutileza del corazón (qalb) se debe a la ductilidad con la que fluctúa de estado en estado. Como el agua, adquiere el color del receptáculo que la contiene... Por eso se llama corazón (qalb), por su capacidad de fluctuación... ${ }^{26}$.

Ibn 'Arabī de Murcia culmina esta compleja Slm al-qulūb ("ciencia de los corazones") en el siglo XIII, y es a quien más cerca podamos sentir del corazón cambiante de las liras unitivas del "Cántico" de san Juan. El murciano teoriza en su Futūhāt que "el corazón se llama corazón (qalb) porque está en perpetua transformación (taqallub) en relación a las moradas" ${ }^{27}$, y en su célebre Tarğumān al-ašwāa $q$ Intérprete de los deseos eleva su teoría espiritual del qalb cambiante a la más alta poesía:

Mi corazón ha devenido capaz de asumir cualquier forma ${ }^{28}$ : es un pasto para gacelas y un convento de monjes cristianos,

Y un templo para ídolos y la Kaaba del peregrino y las Tablas de la Tora y el libro del Corán.

Yo sigo la religión del amor: dondequiera que vayan los camellos del Amor, ahí está mi religión y ahí está mi fe ${ }^{29}$ ).

Michael Sells ha visto que los versos embriagados de Ibn 'Arabī no sólo hacen referencia a la tolerancia religiosa para con todas las revelaciones - Dios se encuentra por igual en todas ellas- sino a algo mucho más hondo: a la morada altísima del corazón extático que es receptivo de cualquier forma:

El corazón que es receptivo de cualquier forma está en un estado de perpetua transformación (el término taqallub juega con los dos significados de la raíz $q-l-b$, "corazón” y "cambio"). El corazón se amolda a, recibe y se con-

25 Cf. Mi ensayo "Para la génesis del pájaro solitario de san Juan de la Cruz" en L. López-Baralt, Huellas del Islam en la literatura española. De fuan Ruiz a Fuan Goytisolo, Madrid: Hiperión, 1985, pp. 59-72.

26 Al-Kubrā, Nağm ad-dīn, Die Fawā̄nh al-Ǧ́amāl wa Fawātih al-Ğalāl des Nağm ad-dìn al-Kubrāa, (Fritz Meier, ed.), Wiesbaden: Franz Steiner Verlag GMBH, 1957, p. 7.

27 Apud Michael Sells, "Ibn 'Arabī’s Garden Among the Flames: The Heart Receptive of Every Form”, En: Mystical Languages of Unsaying. Chicago y Londres: The University of Chicago Press, 1994, pp. 90-115.

28 Su'ād Hakīm traduce con particular belleza: "My heart has become the receptacle of all things" ("Mi corazón se ha convertido en el receptáculo para todas las imágenes" (Hakìm 1993, op. cit., p. 287.)

29 Traduzco al español a partir del original árabe. Cf. la traducción clásica de R. A. Nicholson, acompañada de su original árabe: Muhyi'ddīn Ibn al-'Arabī, Tarjumān al-Ashwāq, A Collection of Mystical Odes. Edición bilingüe árabe-inglesa de R.A. Nicholson, Londres: Royal Asiatic Society, 1911, p. 19. 
vierte en cada una de las formas perpetuamente cambiantes en las cuales la Verdad se revela a sí misma....para lograr un corazón receptivo de toda forma es necesario someterse a un proceso continuo de obliteración del yo individual en el [yo] universal ${ }^{30}$.

El corazón -vale decir, el espejo del alma del sufi- se encuentra en estado de perpetua transformación al ir reflejando las manifestaciones de Dios en cambio perpetuo, sin limitarse a ninguna. Exactamente lo mismo indica san Juan al explicitar las liras espejeantes "Mi Amado, las montañas...": se trata de las manifestaciones continuas de Dios en el azogue interior. El alma del contemplativo, como apunta Sells, "no es tanto una entidad como un evento, un proceso de cambio de perspectiva, de fana $\bar{a}$, un pulir del espejo divino"31. No hay pues por qué atarse a ninguno de estas manifestaciones, porque sólo Dios las puede terminar de conocer de veras e infinitamente, como advirtió san Juan en su propio caso.

Ibn 'Arabī ha alcanzado, en efecto, la más alta de las moradas místicas posibles: la "morada de la nomorada" (maqūm lā maqūm) ${ }^{32}$, en la que el conocimiento intelectual ha quedado atrás para dar paso "a la percepción a través del corazón, asiento de la márifa (el acto de conocer en continua transformación) [“a continually transformative knowing"] ${ }^{33}$. Como el gnóstico no queda definido por ningún atributo de Dios, "puede manifestar atributos conflictivos y contradictorios...." imposible "música callada" y la "soledad sonora" de san Juan de la Cruz.) Ibn 'Arabī posee todas las moradas porque no está atado ya a ninguna, y su estado unificado sólo puede expresarse a través de metáforas inaccesibles al lenguaje ordinario.

Parecería que estamos ante un comentario místico de las liras sanjuanísticas de la unión, vehemente surtidor de visiones hermanado con el incesante manantial verbal de Ibn 'Arabī. Tanto san Juan como Ibn 'Arabī tienen un corazón - un qalb o "gálibo"-incoloro y puro como el agua, y dotado, por eso mismo, de una capacidad proteica que lo capacita para reflejar, en sus incesantes "semblantes plateados", las continuas manifestaciones que la Divinidad hace de Su propia Esencia a sí misma en el alma que es capaz de asumir cualquier forma. De alguna manera san Juan de la Cruz alcanzaría a saber algo de este "conocimiento de los secretos de los movimientos del corazón” (al-\{lm bi-ḥarakāt al-qulüb).

30 Sells, 1994, op. cit., p. 293.

31 Sells, 1988, op. cit., p. 299.

32 Sobre esta "morada de la no-morada" cf. William Chittick, The Sufi Path of Knowledge. Ibn 'Arabì's Metaphysics of Imagination. Albany: State University of New York Press, 1989, p. 375 y The Sufi Path of Love. The Spiritual Teachings of Rūmin. Albany: State University of New York, 1994, p. 170.

33 Sells, 1992, op. cit., p. 91.

34 Chittick, 1989, op. cit., p. 375. 
Las coincidencias entre san Juan y los espirituales del Islam son aún más estrechas. Ya dejé dicho que tanto el corazón de san Juan como el de los sufies que le precedieron funciona a manera de espejo. El espejo invierte las imágenes que refleja, y ello nos devuelve al "Cántico". En medio de su estado transformante, la Esposa anuncia que va a buscar los ojos de su Amado en el aire ("voy de vuelo"), pero a la vez sabemos que los tiene que buscar abajo, en la cristalina fuente de su ipseidad, donde los reflejó. Por más, el Esposo le repite a su amada una orden imposible: "vuélvete, paloma", es decir, "vuélvete" hacia Mí y a la vez lejos de Mí. El enigma del mandato imposible asombra menos a la luz de las coordenadas místicas islámicas. Los sufies preludiaron estos desplazamientos en direcciones contrarias, atendiendo a las desinencias de la voz qalb. Sachiko Murata recuerda que el mandato de "ir y venir" en direcciones opuestas se encuentra implícito en el sentido semántico del término qalb: "El sentido de la palabra (qalb) es ir y venir, cambiar, fluctuar, transformarse" 35 . Precisamente por eso es que Qāšānī (m. 735/1334-35) pone en juego dos desplazamientos invertidos: vislumbra que Dios está a la vez cerca y lejos de él; es decir, emanente e inmanente. Ibn 'Arabī también observa los mismos desplazamientos excluyentes en Las contemplaciones de los misterios de: "Dios me hizo contemplar la perplejidad (hayra) y me dijo: 'Vuelve'. Pero no encontré adónde. Me dijo: 'Acércate'. Pero no encontré adónde. Me dijo: 'Deténte'. Pero no encontré adónde. Me dijo: ‘No te retires'. Y me dejó perplejo" 36 .

La Majestad infinita de Dios nos parece lejana (emanente), pero a la vez percibimos que está tan cerca que compartimos Su esencia divina (inmanente). Esta capacidad del alma de aunar el yin y yang de ambas experiencias se desprende, como dejé dicho, de manera natural de la voz qalb, que, en su variante taqallub, alude a la condición de un espejo que refleja las cosas al revés. (Frente a un espejo es difícil distinguir el "ir" del "venir".) De ahí que las direcciones en las que se "mueve" el corazón de los sufies sean, como vimos, hacia Dios y a la vez lejos de Dios. Justamente así lo explica San Juan en las glosas aclaratorias al "Cántico". A la luz del sufismo, el enigma de estos desplazamientos de ida y vuelta queda aclarado y constituye una lección mística perfectamente congruente.

Este qalb que oscila con movimientos contrarios es capaz, de otra parte, de convertirse en el eje donde confluyen cielos y tierra. Recordemos la febril celebración del "Cántico" de san Juan: en su corazón extático se dan las nupcias bendecidas no sólo de los Esposos sino del Amado con las montañas, los valles, las noches, la música. Los espacios, antes vacíos de Dios, se recuperan en Dios. Lo creado queda redimido en el punto de encuentro del corazón infinito de la Amada. El qalb de los sufies constituyó precisamente ese eje armonizador de contrarios. Para Qayșarī, el qalb, gracias a su posibilidad invertidora (taqallub), constituye un "intermundo entre lo visible y lo invisible, de donde emanan las potencias corporales y espirituales" ${ }^{37}$. Para Kubrā, el qalb es "el vínculo entre la unidad de Dios y

35 Murata, op. cit., 298.

36 Apud Hakīm/Beneito, op. cit., pp. 97-98.

37 Geneviève Gobillot y Paul Ballanfat, "Le coeur et la vie spirituelle chez les mystiques musulmans", en: M. Bertrand, ed. Lumières sur la Voie du Coeur, París: Connaissance des Religions 57-58-59, Revue Trimestrielle en coédition 
la [..] creación"38. La coincidentia opositorum de los sufies y de san Juan no podría lograrse sin un qalb invertidor en el que confluya Dios con la creación.

Difícil saber cuán familiarizado estaría San Juan con estos misterios de la mística islámica que tan cómodamente parecerían desprenderse de sus liras alucinadas. Acaso buena parte de los símiles que derivan de la raíz $q-l-b$ estarían ya lexicalizados en castellano y circularían como moneda común del vocabulario técnico místico conventual. No hay que olvidar en este sentido que incluso otras desinencias de la raíz $q-l-b$ parecerían haber sido aprovechadas por los reformadores del Carmelo. En su "Llama de amor viva" $(3,7)$ San Juan traza una imagen extraña para su alma, que concibe como un pozo de aguas vivas en el que se unen el agua y el fuego, en un milagro que duplica el de la transformación de la amada en el Amado. No es extraño que Nağm al-Dīn al-Kubrā preludiara la curiosa imagen, porque una de las variantes de la raíz $q-l-b$ es precisamente qalīb o "cisterna". Por si fuera poco, también en el pozo del alma del persa las llamas se confunden con el agua en prodigiosa metamorfosis de amor unitivo ${ }^{39}$.

¿Son "casuales" estas coincidencias entre el corazón pulsante y diamantino de san Juan y los sufíes? Barbara Kurtz advierte que "el lenguaje de los místicos no puede transcribir una experiencia sin [...] mediatizarla" ${ }^{\prime 0}$. Es imposible expresar una experiencia teopática sin alguna clase de mediación verbal. Los místicos no pueden evitar sino usar, como añade Stephen Katz -"los símbolos disponibles de su entorno cultural y religioso" ${ }^{41}$.

El símbolo místico del corazón del "Cántico espiritual” de san Juan, espejo fluctuante capaz de reflejar todas las epifanías de la Divinidad sin atarse a ninguna, eje donde confluyen gozosamente el Dios Increado con su creación, pozo de aguas llameantes, no tiene antecedentes en la espiritualidad cristiana y nos plantea un importante problema filogenético. Ajeno a la pesada corporeidad que caracteriza el órgano cordial cristiano, el corazón sanjuanístico encuentra su paralelo más estrecho en el qalb que lo sufies habían desarrollado como órgano de la teopoiesis, basándose en la rica pluralidad de sentidos de la raíz $q-l-b$.

$\mathrm{Al}$ amparo del magisterio inigualable de Miguel Asín, he aprendido a respetar los enigmas del misticismo español, aureolados por una misteriosa fragancia islámica. El símbolo del corazón como espejo iniciático de aguas encendidas en pulsación perpetua en el que se funden el alma y Dios constituye uno de los símiles más complejos del misticismo universal. Admito que es mi símbolo preferido. Pero

avec L'Harmattan, (1999), p. 192.

38 Gobillot y Ballanfat, ibid., p. 194.

39 Exploro más lo dicho en San fuan de la Cruzy el Islam, Madrid: Hiperión, 1989, pp. 49 y ss.

40 Barbara Kurtz, "'The Small Castle of the Soul': Mysticism and Metaphor in the European Middle Ages". Studia Mystica XV,4, 1992, p. 32.

41, Steven T. Katz, "Language, Epistemology, and Mysticism", in Mysticism and Philosophical Analysis, ed. Steven T. Katz, New York: Oxford University Press, 1978, p. 24. 
es tan solo un símil más en la larga cadena de imágenes coincidentes entre san Juan y el Islam que Asín Palacios preludió en sus estudios pioneros. Me gustaría pensar que mi maestro invisible celebraría conmigo este nuevo ejemplo que he podido aportar a los estudios comparatistas hispano-árabes, porque va dedicado a su memoria.

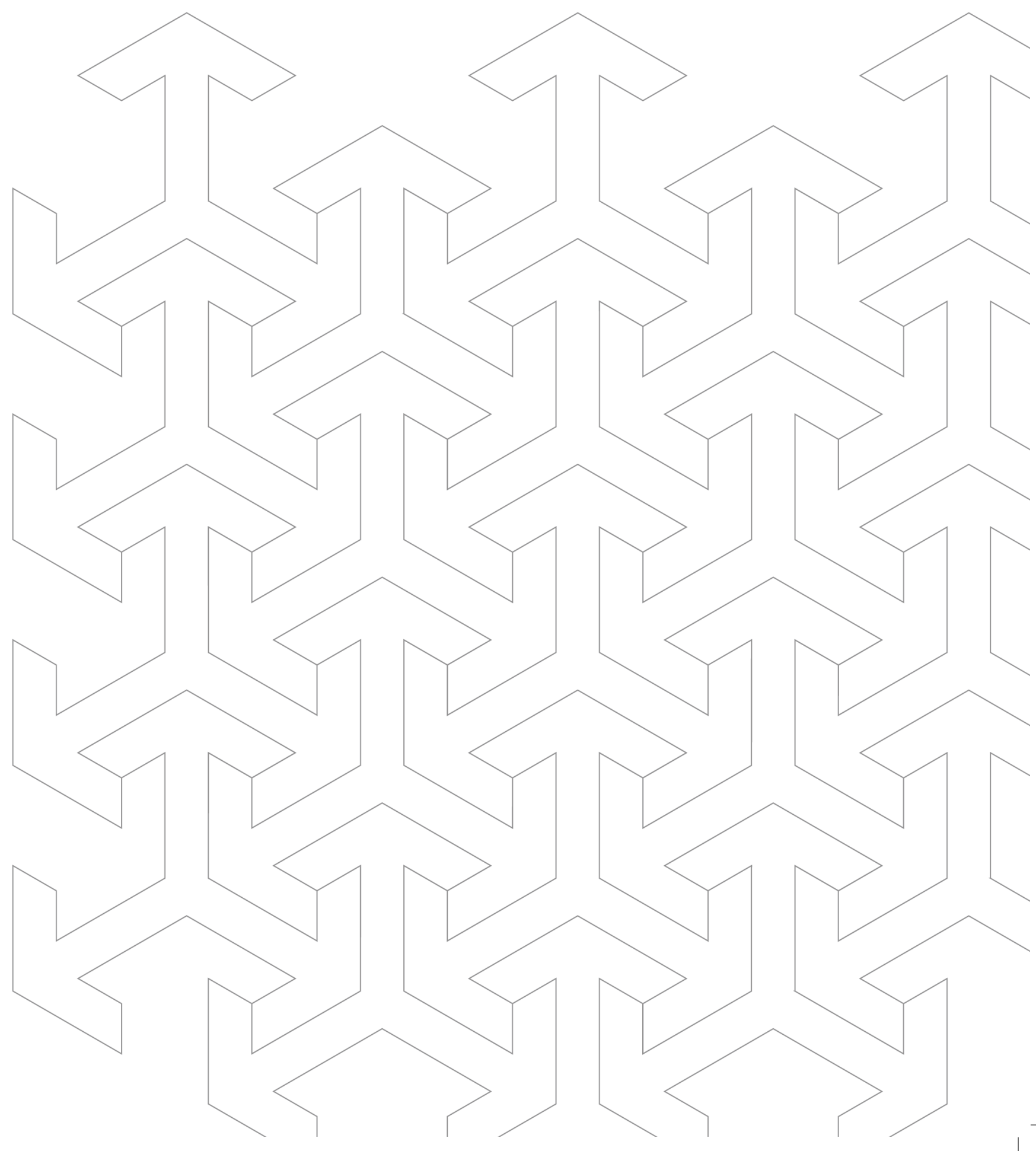

